\title{
Management of the elements of technology for growing of sunflower in the Right-Bank Steppe of Ukraine
}

\section{Hennady Pinkovsky,}

\section{Semen Tanchyk}

National University of Bioresources and Nature Management of Ukraine, 12 Heroes of Defense Street, Kyiv, 03041, Ukraine Email: Gena10.05.1979@ukr.net
The article presents the results of scientific research on the management of technology elements and the influence of factors on the productivity of sunflower in the Right-Bank Steppe of Ukraine. The studies were conducted in the fields of the Institute of Agriculture of the Steppe NAAS, which is located in the black earth zone of the Right-Bank Steppe of Ukraine. The level of sunflower productivity is determined by the conditions of water and nutrient conditions of soil.

Water regime is formed by the weather conditions, the amount of soil moisture reserves, the amount and intensity of rainfall during the year, incl. during the growing season.

The moisture reserves available to plants in the meter layer of soil before sowing, in the flowering phase and before harvesting were different during the years of research, varied in terms of sowing and depended on the density of standing plants. Of particular importance for sunflower plants is the content of available moisture in the $0-100 \mathrm{~cm}$ layer of soil after the formation of baskets. During this period, sunflower intensively consumes available moisture from deeper layers of soil.

The amount of nitrogen, phosphorus and potassium varied significantly over the years and under the influence of different fertilizer backgrounds.

Application of nitrogen fertilizers in combination with phosphorus and potassium, $\mathrm{N}_{40} \mathrm{P}_{40} \mathrm{~K}_{40}+\mathrm{PP}$ and $\mathrm{N}_{40} \mathrm{P}_{40} \mathrm{~K}_{40}$, improves soil nutrition and creates more favourable conditions for growing and developing sunflower plants and maintaining soil fertility.

Under these conditions, the LG 55.82 hybrid with a plant density of 60 housand/ha formed the highest yield for the first sowing period $-3.85 \mathrm{t} / \mathrm{ha}$.

Considering the economic indicators, it is efficient to grow LG 54.85 and LG 55.82 hybrids for the first sowing period. Forward and LG 56.32 sunflower hybrids provide the highest economic performance for the third sowing period. Among the hybrids, it is most economically apropriate to grow LG 55.82 when sowing at soil temperature of $5-6^{\circ} \mathrm{C}$ and plant density of 60 thousand/ha. The net profit in this variant was $22043 \mathrm{UAH} / \mathrm{ha}$, and the level of profitability was $224.1 \%$.

The energy efficiency ratio was the highest in the first sowing period of the LG 55.82 hybrid -4.44 .

Keywords: sunflower, hybrids, sowing time, plant standing density, soil nutrient regime, water regime of soil, yield

\section{INTRODUCTION}

In today's intensive agriculture, there is a growing need for increased production of agricultural products, including sunflower seeds. By scale of distribution, versatility of use and energy value, sunflower is the most important oilseed crop in Ukraine and Europe. 
Increasing sunflower productivity is possible through the development of new and improvement of the existing elements of technology for crop cultivation (Pokoptseva, 2014; Polyakov, Nikitenko, Vakhnenko, 2014; Tkalich, Mamchuk, 2011; Tkalich, Tkalich, Kokhan, 2012).

The choice of the optimum sowing time and plant standing density is a prerequisite for the efficient use of environmental resources for the formation of high crop yields (Kramarenko, Hlushchenko, Dudiak, 1998).

The value of the sunflower crop is determined by many factors, among which is the existence in the soil of moisture and nutrients necessary for the growth and development of plants.

Among the reasons that deter the growth of sunflower seeds, a significant role is played by the lack of soil nutrients (Totskyi, 2014), and the moisture content of the soil in conditions of unstable moisture is limiting and one of the most important factors for creating favourable conditions for plant growth and development (Maliyenko, 2015; Melnyk, Hovorun, 2014).

The accumulation and rational use of soil moistening is most relevant in the Steppe zone with insufficient and unstable moisture, where its total losses on runoff and unproductive evaporation reach half of the annual rainfall rate. Under high anthropogenic loading, the water regime of soil can significantly deteriorate, so it is important to accumulate moisture reserves in the lower part of the root layer $(100-150 \mathrm{~cm})$, from where it gradually moves in the ascending direction under the action of gradients of different nature (Tsyliuryk, Desiatnyk, 2017).

It is ground water reserves and nutrients that in most cases is the cause of low or high sunflower productivity.

The better the crops are provided with moisture, the higher the crop yield the seeds form. The decisive role is played by the fall-winter period and the first half of vegetation (Pustovoit, 1975; Tsylyuryk, Sudak, 2017).

The use of moisture by sunflower crops can to some extent be regulated by the sowing time. Shifting the sowing time to earlier allows changing the conditions of growth and development of sunflower plants, namely - better provided by plants with moisture, and it is possible to bypass critical temperature periods of plant development.
The consumption of plants by elements of nutrients is largely determined by the moisture content of the soil: the better the plants are provided with moisture, the greater the consumption of nitrogen, and, on the contrary, the worse the plants are provided with moisture, the lower their doses (Buriakov, 1992). The system of application of nitrogen fertilizers - doses, terms and methods of application vary depending on soil and climatic conditions, genetic characteristics of soils, but in all regions of Ukraine and on all types of soils their efficiency exceeds yields of phosphorus and potassium fertilizers (Nosko, 2013).

In the system of fertilizers in the Steppe areas, the main fertilizer should be dominated for soil tillage. It provides the placement of fertilizers in the soil layer with guaranteed moisture, which increases the availability elements of nutrients for plants (Hospodarenko, 2018).

The background of nutrition is one of the main elements in the technology of crop cultivation. Fertilizer application increases the content of minerals available to plants in the soil. This changes the chemical composition of soil, its physical and other qualities. Improvement of mineral nutrition has a positive effect on the processes of photosynthesis, provides normal growth and development of plants, crop formation and quality of seeds (Bailly, 2000).

In the face of climate change and the emergence of new hybrids in the production of research to optimize the sowing time and density of plants of different hybrids is actual and important for science and production.

The purpose of the research is to increase productivity by optimizing the sowing time and density of sunflower plants and their effect on the water and nutrient regime of soil in the conditions of the Right-Bank Steppe of Ukraine.

\section{MATERIALS AND METHODS}

The research was conducted in the fields of the Kirovohrad State Agricultural Research Station of the National Academy of Agrarian Sciences of Ukraine (KSASRS NAAS), now the Institute of Agriculture of the Steppe NAAS, which is located in the Black Earth zone of the Right-Bank Steppe of Ukraine.

In the three-factor field experiment the following was investigated: Factor A - medium-early 
Forward sunflower hybrids, LG 56.32, LG 54.85, LG 5582; Factor B - early sowing time (soil temperature at a depth of $10 \mathrm{~cm}-5-6^{\circ} \mathrm{C}$, II $-7-8^{\circ} \mathrm{C}$, III $-9-10^{\circ} \mathrm{C}$ ); Factor $\mathrm{C}$ - the plant density of 50 , 60 and 70 thousand/ha. Replication of the experiment is three times, the total area of the sowing area is $50.4 \mathrm{~m}^{2}$, the accounting area is $25.2 \mathrm{~m}^{2}$. The precursor is spring barley.

The main difference of the soil cover is the ordinary heavy soil loam. The humus content is $4.72 \%$, easily hydrolyzing nitrogen 104 , mobile phosphorus 191 and exchangeable potassium $142 \mathrm{mg}$ per $\mathrm{kg}$ of soil, mobile forms of manganese, zinc and boron, respectively, 3.1, 0.35 and $1.76 \mathrm{mg}$ per $\mathrm{kg}$ of soil. The reaction of soil solution is $\mathrm{pH}-5.8$.

The climatic conditions of the Institute of IAS NAAS are typical for the Right-Bank Steppe of Ukraine with the temperate continental climate. This is confirmed by the daily and annual amplitude of air temperature, as well as by significant fluctuations in the annual weather conditions. The average annual rainfall is $499 \mathrm{~mm}$ per year.

The weather conditions for research differed, both from each other and from the average longterm indicators in terms of precipitation and temperature.

The moisture content of soil was determined by the thermostatic-weight method.

The nitrogen content was determined by a ion selective ionometer I-160 M according to DSTU ISO 4729: 2007.
The content of mobile phosphorus was determined by Machigin (DSTU ISO 4114-2002), potassium by Maslova (GOST - 26210-91).

Statistical analysis of the results of studies was performed by the multivariate dispersion method, the calculations were performed using MS Excel Agcstat.

\section{RESULTS AND DISCUSSION}

\section{Dynamics of soil moisture content}

The researches made it possible to establish that the level of sunflower productivity is determined by the conditions of water and nutritional regime of soil.

The presence of moisture in soil is one of the limiting factors that ensure the yield. Its main source is atmosphere precipitation (Maliyenko, 2015).

Sunflower for formation of high seed yield requires deep soaking of soil in spring, presence of $165-185 \mathrm{~mm}$ of productive moisture in the root layer $0-150 \mathrm{~cm}$ and sufficient $(300-400 \mathrm{~mm})$ rainfall during the growing season (Tsyliuryk, 2018).

Stocks of productive moisture in the meter layer of soil during sowing significantly influenced the dynamics of emergence of seedlings (Fig. 1).

So in 2016, the moisture reserve for the first sowing period $-5-6^{\circ} \mathrm{C}(6$ April $)$ - was $181.9 \mathrm{~mm}$, for the second $-7-8^{\circ} \mathrm{C}(10$ April $)-178.8 \mathrm{~mm}$,

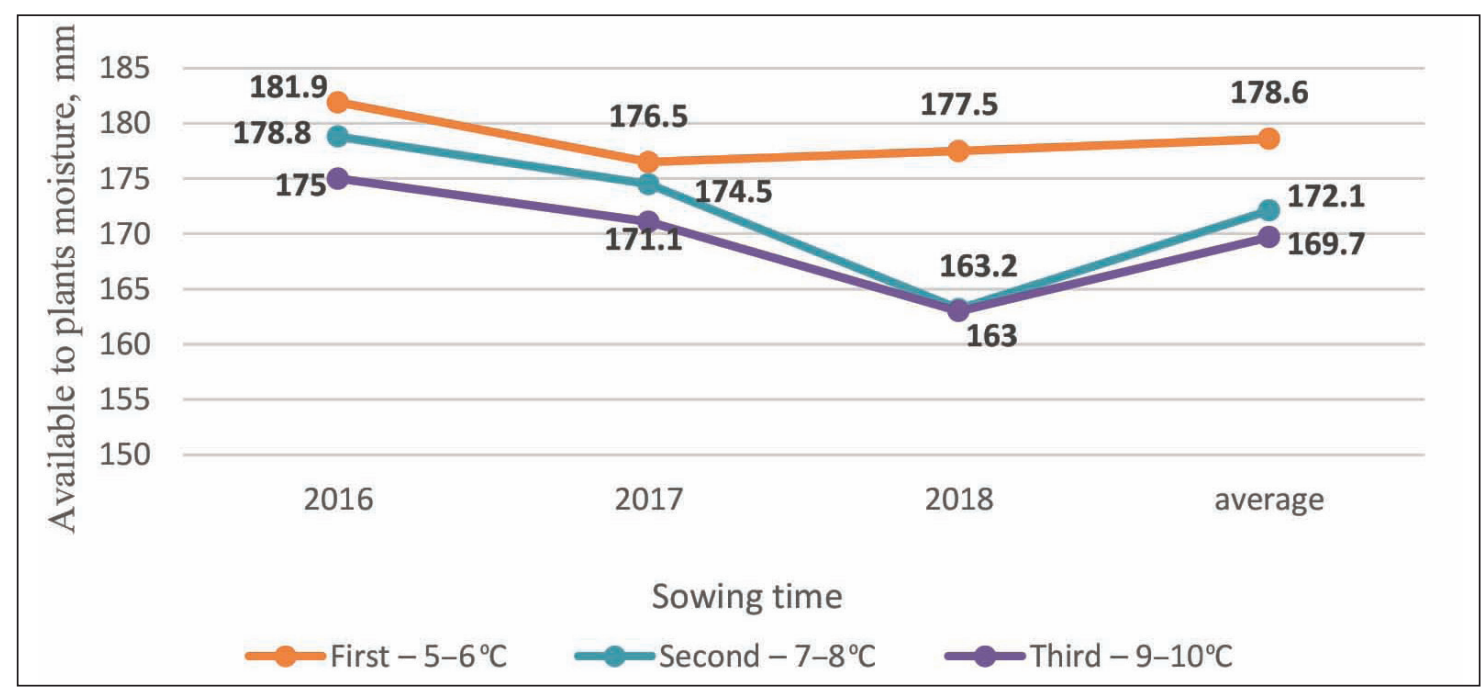

Fig. 1. The content of moisture available to plants in the soil layer $0-100 \mathrm{~cm}$ at the time of sunflower sowing 
for the third $-9-10^{\circ} \mathrm{C}(13$ April $)-175.0 \mathrm{~mm}$; in 2017, respectively, for the first sowing period $-5-6^{\circ} \mathrm{C}$ (7 April) - it was $176.5 \mathrm{~mm}$, for the second $-7-8^{\circ} \mathrm{C}$ (12 April) $-174.5 \mathrm{~mm}$, for the third $-9-10^{\circ} \mathrm{C}$ (28 April) $-171.1 \mathrm{~mm}$; in 2018 , respectively, for the first sowing period $-5-6^{\circ} \mathrm{C}$ (6 April) - it was $177.5 \mathrm{~mm}$, for the second $-7-8^{\circ} \mathrm{C}$ (12 April) $-163.2 \mathrm{~mm}$, for the third $-9-10^{\circ} \mathrm{C}$ (24 April) - $163.0 \mathrm{~mm}$. On average, during the years of research, the most available moisture in the $0-100 \mathrm{~cm}$ soil layer was during the first sowing period - when it was heated to a depth of seed $5-6^{\circ} \mathrm{C}-178.6 \mathrm{~mm}$, for the second sowing period it was $172.1 \mathrm{~mm}$, and for the third sowing period it was $169.7 \mathrm{~mm}$.

Moisture reserves in the $0-10 \mathrm{~cm}$ soil layer remained high at the time of sowing (Fig. 2).

This is due to low temperatures, compensated by the increased relative humidity, low evaporation of soil moisture and precipitations during this period. Thus, during the first sowing period, the moisture reserve was $25.0 \mathrm{~mm}$, in the second it was $24.4 \mathrm{~mm}$, and in the third sowing period $23.6 \mathrm{~mm}$, that is, a gradual decrease in the amount of moisture available to plants in the sowing layer of soil.

In the flowering phase, sunflower plants are too sensitive to lack of moisture. During flowering, plants consume moisture from the soil layer $140-200 \mathrm{~cm}$. With soil moisture deficiency, baskets of a smaller diameter are formed, the forma- tion of new flowers is delayed, and the number of well-filled, full-fledged seedlings is sharply reduced. Insufficient moisture supply adversely affects the linear growth and development of the leaf area, which in turn affects the productivity of plants (Skydan, 2016).

The studies show that the moisture available to plants in the meter layer of soil in the flowering phase was different during the years of research, varied in terms of sowing and depended on the density of plants (Fig. 3).

After forming the baskets and before the ripening of seeds, the water consumption is approximately $100-120 \mathrm{~mm}$, and from the beginning of ripening to the full ripeness of seeds about 100$130 \mathrm{~mm}$ of moisture is used (Kartamyshev, Tymonov, Zelenyn, 2008). Water reserves of about $60 \mathrm{~mm}$ in the meter layer of soil in the flowering phase are not sufficient for good growth and development of plants (Skydan, Skydan, Kostromitin, 2013).

Thus, according to the average data of 20162018, the highest reserve of moisture available to plants in the soil layer $0-100 \mathrm{~cm}$, in crops of Forward hybrids, LG 56.32, LG 54.85 and LG 55.82, was at the density of standing plants 60 thousand per ha, for the first sowing period - in the flowering phase it was $127 \mathrm{~mm}$, for the second sowing period $121 \mathrm{~mm}$, for the third sowing period $121 \mathrm{~mm}$. For plant densities of 50 thousand per ha for the first sowing period $-5-6^{\circ} \mathrm{C}$, in crops

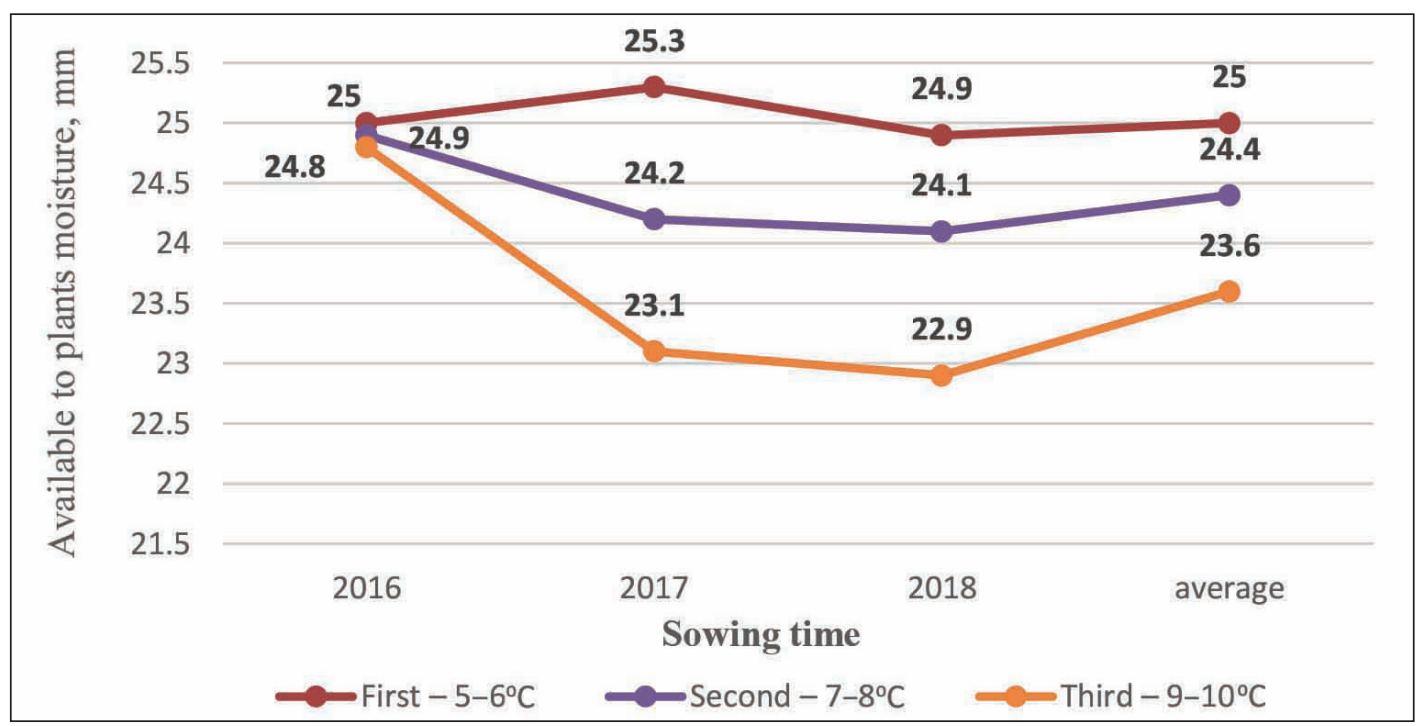

Fig. 2. The content of moisture available to plants in the soil layer $0-10 \mathrm{~cm}$ at the time of sunflower sowing 


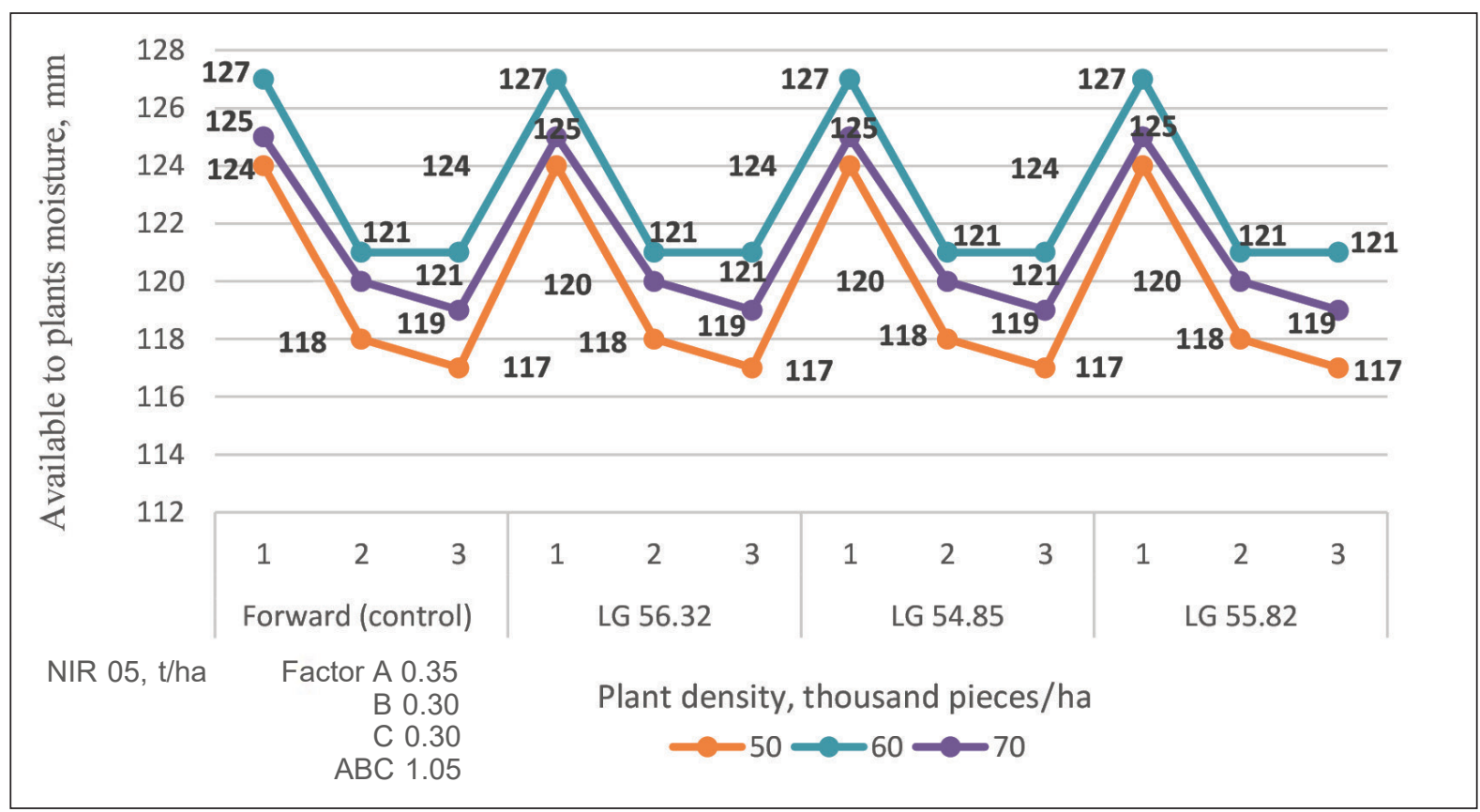

Fig. 3. The content of available moisture in the $0-100 \mathrm{~cm}$ layer of soil, $\mathrm{mm}$, depending on the sowing time and density of standing sunflower plants in the flowering phase (average for 2016-2018)

of Forward hybrids, LG 56.32, LG 54.85 and LG 55.82 the available moisture in the flowering phase was $124 \mathrm{~mm}$, for the second sowing period $-7-8^{\circ} \mathrm{C}-118 \mathrm{~mm}$, and for the third sowing period $-9-10^{\circ} \mathrm{C}-117 \mathrm{~mm}$. In the case of the increase of plant standing density up to 70 thousand per ha, the reserve of moisture available to plants was $125 \mathrm{~mm}$ in the first sowing period, $125 \mathrm{~mm}$ in the flowering stage, $120 \mathrm{~mm}$ in the second sowing period, and $119 \mathrm{~mm}$ in the third sowing period.

\section{Influence of elements of nutrition on the fertility of soil and productivity of sunflower}

Sunflower forms high-energy biomass, which consumes a large number of mineral nutrients. It uses an average of $5.8-6.2 \mathrm{~kg}$ of nitrogen, $2.5-2.7 \mathrm{~kg}$ of phosphorus and $18.3-18.9 \mathrm{~kg}$ of potassium to form 1 centner of seed. The level of consumption elements of nutrients depends on many factors: terms and methods of fertilizer application, moisture supply weather conditions, as well as the genetic characteristics of the variety or hybrid (Kovalenko, 2016).

For the formation of high productivity of sunflower, as well as for maintaining the fertility of the soil at the proper level, conditions must be created for the complete providing of soil with nutrients.
In general, for three years of studies, the content of nitrate nitrogen in the arable soil was at the level of low $\mathrm{NO}_{3}(0.60-6.60 \mathrm{mg} / \mathrm{kg})$, ammonium nitrogen at the average level of $\mathrm{NH}_{4}$ (17.5$28.4 \mathrm{mg} / \mathrm{kg}$ ), phosphorus and potassium at high and high levels of safety $\left(\mathrm{P}_{2} \mathrm{O}_{5}-166.9-324.0 \mathrm{mg} / \mathrm{kg}\right.$; $\mathrm{K}_{2} \mathrm{O}-96.0-193.0 \mathrm{mg} / \mathrm{kg}$ ), Table 1.

The amount of nitrogen, phosphorus and potassium changed significantly over the years and under the influence of different fertilizer backgrounds.

The application of the fertilizer system for growing sunflower in 2016 contributed to a significant increase in phosphorus on plots when making $\mathrm{N}_{40} \mathrm{P}_{40} \mathrm{~K}_{40}+\mathrm{PP}$ and was $232.8 \mathrm{mg} / \mathrm{kg}$ of soil, in the non-fertilizer version the phosphorus content was $210.9 \mathrm{mg} / \mathrm{kg}$ of soil and in the variant $\mathrm{N}_{40} \mathrm{P}_{40} \mathrm{~K}_{40}$ it was $195.3 \mathrm{mg} / \mathrm{kg}$ of soil, respectively.

The introduction of $\mathrm{N}_{40} \mathrm{P}_{40} \mathrm{~K}_{40}$ contributed to the reduction of phosphorus by $37.5 \mathrm{mg} / \mathrm{kg}$ of soil or by $16.2 \%$ compared to the variant $\mathrm{N}_{40} \mathrm{P}_{40} \mathrm{~K}_{40}+\mathrm{PP}$ and $15.6 \mathrm{mg} / \mathrm{kg}$ of soil or $7.4 \%$ compared to the fertilizer-free version.

Making $\mathrm{N}_{40} \mathrm{P}_{40} \mathrm{~K}_{40}+\mathrm{PP}$ contributed to the increase of nitric nitrogen $\left(\mathrm{NO}_{3}\right)$ content by $1.35 \mathrm{mg} / \mathrm{kg}$ of soil or by $37.5 \%$ compared to the version without fertilizers. Ammonium 
Table 1. The content of nutrients in the arable soil $(0-30 \mathrm{~cm})$, depending on the fertilizer of sunflower for 2016-2018

\begin{tabular}{|c|c|c|c|c|c|}
\hline Years & Fertilizer system & $\mathrm{NO}_{3} \mathrm{mg} / \mathrm{kg}$ & $\mathrm{NH}_{4} \mathrm{mg} / \mathrm{kg}$ & $\mathrm{P}_{2} \mathrm{O}_{5} \mathrm{mg} / \mathrm{kg}$ & $\mathrm{K}_{2} \mathrm{O} \mathrm{mg} / \mathrm{kg}$ \\
\hline \multirow{3}{*}{2016} & No fertilizer & 2.25 & 17.5 & 210.9 & 96.0 \\
\hline & $\mathrm{N}_{40} \mathrm{P}_{40} \mathrm{~K}_{40}$ & 2.83 & 24.6 & 195.3 & 122.5 \\
\hline & $\mathrm{N}_{40} \mathrm{P}_{40} \mathrm{~K}_{40}+\mathrm{PP}$ & 3.60 & 18.8 & 232.8 & 137.3 \\
\hline \multirow{3}{*}{2017} & No fertilizer & 3.50 & 18.6 & 186.0 & 109.6 \\
\hline & $\mathrm{N}_{40} \mathrm{P}_{40} \mathrm{~K}_{40}$ & 6.60 & 19.9 & 266.5 & 163.0 \\
\hline & $\mathrm{N}_{40} \mathrm{P}_{40} \mathrm{~K}_{40}+\mathrm{PP}$ & 6.20 & 28.4 & 166.9 & 169.0 \\
\hline \multirow{3}{*}{2018} & No fertilizer & 0.81 & 17.9 & 271.9 & 152.0 \\
\hline & $\mathrm{N}_{40} \mathrm{P}_{40} \mathrm{~K}_{40}$ & 0.76 & 24.2 & 166.9 & 193.0 \\
\hline & $\mathrm{N}_{40} \mathrm{P}_{40} \mathrm{~K}_{40}+\mathrm{PP}$ & 0.60 & 17.6 & 324.0 & 145.0 \\
\hline
\end{tabular}

* PP, by-products of the predecessor.

nitrogen $\left(\mathrm{NH}_{4}\right)$ content in the soil was higher when $\mathrm{N}_{40} \mathrm{P}_{40} \mathrm{~K}_{40}$ was applied and amounted to $24.6 \mathrm{mg} / \mathrm{kg}$ of soil, which is $28.9 \%$ compared to the fertilizer-free version.

In 2017, the phosphorus content was higher in the $\mathrm{N}_{40} \mathrm{P}_{40} \mathrm{~K}_{40}$ background and was $266.5 \mathrm{mg} / \mathrm{kg}$ of soil, which is higher than in the non-fertilizer version by $80.5 \mathrm{mg} / \mathrm{kg}$ of soil or $30.3 \%$ and in the variant $\mathrm{N}_{40} \mathrm{P}_{40} \mathrm{~K}_{40}+\mathrm{PP}$ on $99.6 \mathrm{mg} / \mathrm{kg}$ soil or $37.4 \%$.

The introduction of $\mathrm{N}_{40} \mathrm{P}_{40} \mathrm{~K}_{40}$ contributed to an increase in the nitrate nitrogen $\left(\mathrm{NO}_{3}\right)$ content of $3.1 \mathrm{mg} / \mathrm{kg}$ soil or $47.0 \%$ compared to the non-fertilizer version and $6.1 \%$ with the $\mathrm{N}_{40} \mathrm{P}_{40} \mathrm{~K}_{40}+\mathrm{PP}$ variant. Ammonium nitrogen $\left(\mathrm{NH}_{4}\right)$ content in soil was higher when $\mathrm{N}_{40} \mathrm{P}_{40} \mathrm{~K}_{40}+\mathrm{PP}$ was applied and amounted to $28.4 \mathrm{mg} / \mathrm{kg}$ of soil, up by $34.6 \%$ compared to the non-fertilizer version.

Making $\mathrm{N}_{40} \mathrm{P}_{40} \mathrm{~K}_{40}+\mathrm{PP}$ while growing sunflower in 2018 significantly increased the phosphorus content of the fertilizer-free background and the $\mathrm{N}_{40} \mathrm{P}_{40} \mathrm{~K}_{40}$ background. The phosphorus content was $324.0,271.9$ and $166.9 \mathrm{mg} / \mathrm{kg}$ of soil, which is more than the fertilizer-free version by $16.1 \%$ and the $\mathrm{N}_{40} \mathrm{P}_{40} \mathrm{~K}_{40}$ variant by $48.5 \%$.

Nitrogen $\left(\mathrm{NO}_{3}\right)$ content in soil was almost unchanged with $\mathrm{N}_{40} \mathrm{P}_{40} \mathrm{~K}_{40}$ and $\mathrm{N}_{40} \mathrm{P}_{40} \mathrm{~K}_{40}+\mathrm{PP}$, this indicator varied from 0.60 to $0.81 \mathrm{mg} / \mathrm{kg}$ of soil and was higher in the non-fertilizer version by $26 \%$.

The introduction of $\mathrm{N}_{40} \mathrm{P}_{40} \mathrm{~K}_{40}$ increased the content of ammoniacal nitrogen $\left(\mathrm{NH}_{4}\right)$ by $6.3 \mathrm{mg} / \mathrm{kg}$ of soil or by $26.1 \%$ compared to the non-fertilizer variant.
Thus, when growing sunflower in 2016-2017, making $\mathrm{N}_{40} \mathrm{P}_{40} \mathrm{~K}_{40}+\mathrm{PP}$ contributed to the increase in the soil potassium content of 137.3 and $169.0 \mathrm{mg} / \mathrm{kg}$ of soil, which was by 10.8 and $3.6 \%$ more than the $\mathrm{N}_{40} \mathrm{P}_{40} \mathrm{~K}_{40}$ variant, and by 30.1 and $35.2 \%$ compared to the non-fertilizer variant.

In 2018, the potassium content of soil was higher in the $\mathrm{N}_{40} \mathrm{P}_{40} \mathrm{~K}_{40}$ background and was $193.0 \mathrm{mg} / \mathrm{kg}$, which was by $24.9 \%$ more than in the $\mathrm{N}_{40} \mathrm{P}_{40} \mathrm{~K}_{40}+\mathrm{PP}$ version and by $21.3 \%$ in the fertilizer-free version.

\section{Sunflower productivity depending on sowing time and plant standing density}

One of the main levers of combating the high variability of sunflower yields over the years is not only a broad focus on achieving the potential productivity of new hybrids, but also taking into account the general and specific adaptability of plants to the conditions of the regions (Nosenko, 2011). During the rapid onset of warm spring early sowing crops provided no less than the average. Sowing at a later date (except for some years) led to a decrease in yield (Kovalenko, 2005; Mynkovskyy, Polyakov, 2007).

The research established a significant dependence of yield of sunflower hybrids on the density of plants, weather conditions, biological features of hybrids and sowing time (Table 2).

In general, over the three years of research, the highest yields of the hybrids LG 5582, LG 54.85, LG 56.32 and Forward was obtained at a density of 60 thousand plants/ha. In the first sowing period, 
Table 2. Yield of sunflower hybrids, depending on the sowing time and density of plants, $t / h a$ (average for 2016-2018)

\begin{tabular}{|c|c|c|c|c|c|c|c|c|c|c|}
\hline \multirow{3}{*}{ Hybrid } & \multirow{3}{*}{ Year } & \multicolumn{3}{|c|}{ Soil temperature $5-6^{\circ} \mathrm{C}$} & \multicolumn{3}{|c|}{ Soil temperature $7-8^{\circ} \mathrm{C}$} & \multicolumn{3}{|c|}{ Soil temperature $9-10^{\circ} \mathrm{C}$} \\
\hline & & \multicolumn{9}{|c|}{ Plant density, thousand pieces/ha } \\
\hline & & 50 & 60 & 70 & 50 & 60 & 70 & 50 & 60 & 70 \\
\hline \multirow{4}{*}{$\begin{array}{l}\text { Forward (control, } \\
\text { standard) }\end{array}$} & 2016 & 2.70 & 2.62 & 2.65 & 2.87 & 2.74 & 2.41 & 2.79 & 2.73 & 2.70 \\
\hline & 2017 & 3.02 & 2.91 & 2.66 & 3.27 & 3.29 & 2.79 & 3.21 & 3.37 & 3.27 \\
\hline & 2018 & 3.12 & 3.29 & 2.99 & 2.82 & 2.93 & 3.06 & 2.87 & 3.17 & 2.81 \\
\hline & Average & 2.94 & 2.94 & 2.76 & 2.98 & 2.98 & 2.75 & 2.95 & 3.09 & 2.92 \\
\hline \multirow{4}{*}{ LG 56.32} & 2016 & 2.79 & 2.75 & 2.68 & 3.06 & 3.62 & 3.29 & 3.24 & 3.41 & 3.35 \\
\hline & 2017 & 3.11 & 3.42 & 3.56 & 3.19 & 3.47 & 3.23 & 3.30 & 3.55 & 3.7 \\
\hline & 2018 & 3.46 & 3.76 & 3.46 & 3.28 & 3.51 & 3.33 & 3.53 & 3.90 & 3.30 \\
\hline & Average & 3.12 & 3.30 & 3.23 & 3.17 & 3.5 & 3.28 & 3.35 & 3.62 & 3.45 \\
\hline \multirow{4}{*}{ LG 54.85} & 2016 & 3.26 & 3.50 & 3.00 & 3.33 & 3.33 & 3.18 & 3.23 & 3.12 & 2.93 \\
\hline & 2017 & 3.49 & 3.69 & 3.62 & 3.7 & 3.99 & 3.52 & 3.98 & 4.10 & 3.58 \\
\hline & 2018 & 3.53 & 3.74 & 3.41 & 3.37 & 3.24 & 3.27 & 3.58 & 3.63 & 3.15 \\
\hline & Average & 3.42 & 3.64 & 3.34 & 3.46 & 3.51 & 3.32 & 3.59 & 3.61 & 3.22 \\
\hline \multirow{4}{*}{ LG 55.82} & 2016 & 3.22 & 3.27 & 2.70 & 3.26 & 3.21 & 3.38 & 3.28 & 2.96 & 3.38 \\
\hline & 2017 & 3.95 & 4.04 & 3.74 & 3.91 & 4.16 & 3.54 & 3.69 & 3.98 & 3.59 \\
\hline & 2018 & 3.74 & 4.24 & 3.58 & 3.47 & 3.83 & 3.84 & 3.86 & 3.99 & 3.79 \\
\hline & Average & 3.63 & 3.85 & 3.33 & 3.54 & 3.73 & 3.58 & 3.60 & 3.64 & 3.58 \\
\hline NIR 05, t/ha for & \multicolumn{10}{|c|}{$\begin{array}{c}\text { Factors A } 0.13 \\
\text { Factors B } 0.11 \\
\text { Factors C } 0.11 \\
\text { Total ABC } 0.40\end{array}$} \\
\hline
\end{tabular}

the highest seed yield of $3.85 \mathrm{t} / \mathrm{ha}$ was provided by the LG 55.82 hybrid, which was by $5.5 \%$ more than in the third term and by $3.2 \%$ in the second sowing period. The plants of the LG 54.85 hybrid formed a seed yield of $3.64 \mathrm{t} / \mathrm{ha}$ for sowing in the first term, which is by $0.9 \%$ more for the third term and by $3.6 \%$ for the second sowing period. For the sowing in the third term, the highest seed yields were

Table 3. Results of the three-factor analysis of dispersion (average for 2016-2018)

\begin{tabular}{|c|c|c|c|c|c|c|}
\hline Source of variation & Sum of squares & Degrees of freedom & Dispersion & $\mathbf{F}_{\text {fact }}$ & $\mathbf{F}_{\text {tab095 }}$ & Influence, \% \\
\hline Factor A & 8.0 & 3.0 & 2.6 & 44.9 & 2.7 & 47.5 \\
\hline Factor B & 0.6 & 2.0 & 0.3 & 4.7 & 3.1 & 3.4 \\
\hline Factor C & 1.0 & 2.0 & 0.4 & 8.4 & 3.1 & 5.4 \\
\hline$A * B$ & 0.9 & 6.0 & 0.1 & 2.2 & 2.2 & 5.5 \\
\hline $\mathrm{A}^{\star} \mathrm{C}$ & 0.7 & 6.0 & 0.1 & 1.8 & 2.2 & 3.9 \\
\hline $\mathrm{B}^{\star} \mathrm{C}$ & 0.4 & 4.0 & 0.1 & 1.8 & 2.5 & 2.5 \\
\hline$A^{\star} B^{\star} C$ & 0.6 & 12.0 & 0.0 & 0.7 & 1.9 & 3.7 \\
\hline \multirow{5}{*}{$\begin{array}{l}\text { NIR 05, } \\
\text { t/ha for }\end{array}$} & \multicolumn{6}{|c|}{ Factor } \\
\hline & Year & A & B & $\mathrm{C}$ & \multicolumn{2}{|r|}{$\mathrm{ABC}$} \\
\hline & 2016 & 0.15 & 0.13 & 0.13 & \\
\hline & 2017 & 0.12 & 0.10 & 0.10 & \multicolumn{2}{|r|}{$\begin{array}{l}0.45 \\
0.36\end{array}$} \\
\hline & 2018 & 0.13 & 0.11 & 0.11 & \multicolumn{2}{|r|}{0.39} \\
\hline
\end{tabular}


formed by hybrids of Forward and LG, 56.32-3.09 and $3.62 \mathrm{t} / \mathrm{ha}$, which is higher by 3.6 and $3.4 \%$ for the second term, and by 4.9 and $8.9 \%$, respectively, for the first term. Hybrids of sunflower LG 56.32, LG 54.85 and LG 55.82 significantly exceeded the control variant by seed yield. Thus, the LG 55.82 sunflower hybrid exceeded the Forward hybrid yield by $0.91 \mathrm{t} / \mathrm{ha}$, or $23.7 \%$; LG 54.85 by $0.7 \mathrm{t} / \mathrm{ha}$, or $19.3 \%$; LG 56.32 up to 0.53 t/ha, or $14.7 \%$.

Thus, sunflower productivity varied significantly under the influence of the morphobiological features of the hybrid (the proportion of impact was $47.5 \%)$, weather conditions $(28.1 \%)$, density of standing plants $(5.4 \%)$, sowing time (3.4\%); plant density ${ }^{*}$ hybrid and sowing time ${ }^{*}$ hybrid had a significant effect (Fig. 4).

\section{Economic and energy efficiency of the improved elements of sunflower production technology}

The introduction of new hybrids with a high adaptive potential of both domestic and foreign breeding, using of high quality seeds and using of modern growing technologies should ensure a high level of production efficiency due to a significant increase in yield at the optimal level of acreage (Kyrychenko, Kolomats'ka, Maklyak, Syvenko, 2010). Of great importance is the concentration of crops in the regions with the most favourable con- ditions, which is why sunflower production is one of the most profitable (Sharkovs'ka, 2017).

The calculation of the cost-effectiveness of growing sunflower confirmed that early sowing time leads to a higher level of profitability than late ones. The criteria for the degree of efficiency were the level of cost of production, the amount of net profit per $1 \mathrm{ha}$, calculated as the difference between the cost of the crop per unit area and the cost of its production (Table 4).

It should be noted that production costs increased from the first to the third sowing periods due to the additional sowing cultivation in the second term and in the third. Costs were also determined by the pre-harvesting moisture of grain. Costs for the first sowing period fluctuated within 8677-9835 UAH/ha, for the second 8793-9951 UAH/ha and for the third increased to $8909-10067 \mathrm{UAH} / \mathrm{ha}$.

The lowest seed cost was obtained when growing the hybrid LG 55.82-2554.5 UAH/t for the first sowing period, and this variant recorded the highest profitability in the experiment $-224.1 \%$. Among the hybrids, it is most economicaly feasible to grow LG 55.82 when sowing at $5-6^{\circ} \mathrm{C}$ soil temperatures. The net profit in this variant was $22043 \mathrm{UAH} / \mathrm{ha}$, and the level of profitability was $224.1 \%$.

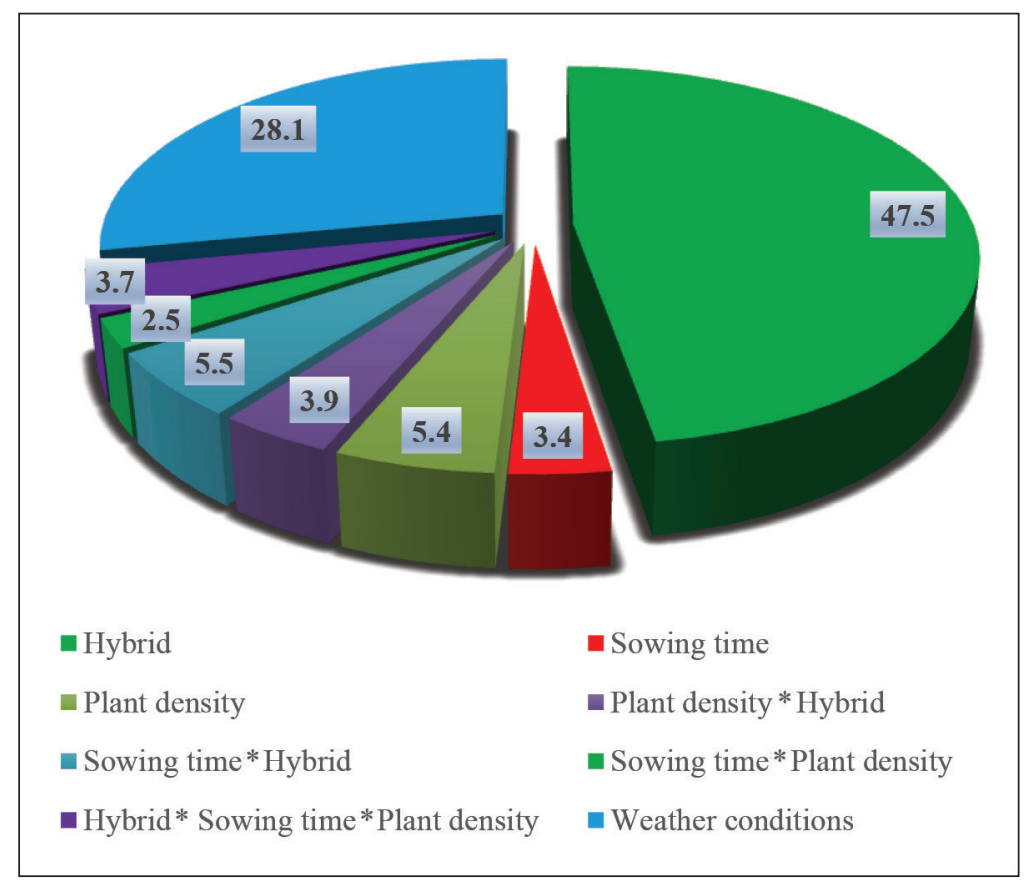

Fig. 4. Part of the influence of factors on the yield of sunflower seeds (average for 2016-2018) 
Table 4. Economic efficiency of the cultivation of sunflower at standing density of thousand/ha at different sowing periods (average for 2016-2018)

\begin{tabular}{|c|c|c|c|c|c|c|c|}
\hline Hybrid & $\begin{array}{l}\text { Sowing } \\
\text { time }\end{array}$ & $\begin{array}{c}\text { Yield, } \\
\text { t/ha }\end{array}$ & $\begin{array}{l}\text { The cost of } \\
\text { the crop, UAH/t }\end{array}$ & $\begin{array}{c}\text { Cost of seeds, } \\
\text { UAH/t }\end{array}$ & $\begin{array}{l}\text { Costs, } \\
\text { UAH/ha }\end{array}$ & $\begin{array}{l}\text { Net profit, } \\
\text { UAH/ha }\end{array}$ & $\begin{array}{c}\text { Profitability } \\
\text { level, \% }\end{array}$ \\
\hline \multirow{3}{*}{$\begin{array}{l}\text { Forward } \\
\text { (control, } \\
\text { standard) }\end{array}$} & $5-6^{\circ} \mathrm{C}$ & 2.94 & 24343 & 2951.3 & 8677 & 15666 & 180.5 \\
\hline & $7-8^{\circ} \mathrm{C}$ & 2.98 & 24674 & 2950.6 & 8793 & 15881 & 180.6 \\
\hline & $9-10^{\circ} \mathrm{C}$ & 3.09 & 25585 & 2883.1 & 8909 & 16676 & 187.1 \\
\hline \multirow{3}{*}{ LG 56.32} & $5-6^{\circ} \mathrm{C}$ & 3.30 & 27324 & 2827.8 & 9332 & 17992 & 192.7 \\
\hline & $7-8^{\circ} \mathrm{C}$ & 3.5 & 28980 & 2699.4 & 9448 & 19532 & 206.7 \\
\hline & $9-10^{\circ} \mathrm{C}$ & 3.62 & 29973 & 2641.9 & 9564 & 20409 & 213.3 \\
\hline \multirow{3}{*}{ LG 54.85} & $5-6^{\circ} \mathrm{C}$ & 3.64 & 30139 & 2701.0 & 9832 & 20307 & 206.5 \\
\hline & $7-8^{\circ} \mathrm{C}$ & 3.51 & 29062 & 2834.1 & 9948 & 19114 & 192.1 \\
\hline & $9-10^{\circ} \mathrm{C}$ & 3.61 & 29890 & 2787.8 & 10064 & 19826 & 196.9 \\
\hline \multirow{3}{*}{ LG 55.82} & $5-6^{\circ} \mathrm{C}$ & 3.85 & 31878 & 2554.5 & 9835 & 22043 & 224.1 \\
\hline & $7-8^{\circ} \mathrm{C}$ & 3.73 & 30884 & 2667.8 & 9951 & 20933 & 210.3 \\
\hline & $9-10^{\circ} \mathrm{C}$ & 3.64 & 30139 & 2765.6 & 10067 & 20072 & 199.3 \\
\hline
\end{tabular}

In addition to the economic evaluation of the technology of sunflower cultivation, the energy assessment of the level of total energy costs, the cost of production of 1 centner of seeds, energy output per hectare, as well as the level of energy efficiency (LEE) was carried out. The efficiency ratio was the highest during the first sowing period and was 3.38-4.44. In the second term, the value of LEE ranged from 3.22 to 4.03 and in the third period it was from 3.13 to 3.69.

\section{CONCLUSIONS}

The water regime is formed by weather conditions, the amount of soil moisture reserves, the amount and intensity of rainfall during the year, incl. during the vegetative period. To a large extent, soil's water regime depends on the morphological features of the hybrids, the plant standing density, the sowing time and the cultivation technology. Under these conditions, crops with plant density of 60 thousand/ha contributed to the formation of the highest yield, compared with other options.

For the first sowing period, the highest seed yields were provided by the LG $55.82-3.85 \mathrm{t} / \mathrm{ha}$ and LG 54.85 hybrids - 3.64 t/ha, while the Forward and LG 56.32 hybrids for the third term sowed 3.09 and $3.62 \mathrm{t} / \mathrm{ha}$, respectively.

Application of nitrogen fertilizers in combination with phosphorus and potassium, $\mathrm{N}_{40} \mathrm{P}_{40} \mathrm{~K}_{40}+$ $\mathrm{PP}$ and the $\mathrm{N}_{40} \mathrm{P}_{40} \mathrm{~K}_{40}$, improves soil nutrition and creates more favourable conditions for the growth and development of sunflower plants and for maintaining soil fertility.

Considering the economic indicators, it is efficient to grow LG 54.85 and LG 55.82 hybrids for the first sowing period. Forward and LG 56.32 sunflower hybrids provide the highest economic performance for the third sowing period.

Among the hybrids, it is most economically appropriate to grow LG 55.82 when sowing at soil temperatures of $5-6^{\circ} \mathrm{C}$ and plant density of 60 thousand/ha. The net profit in this variant was $22043 \mathrm{UAH} / \mathrm{ha}$, and the level of profitability was $224.1 \%$.

The energy efficiency ratio was the highest in the first sowing period of the LG 55.82 hybrid and was 4.44 .

Thus, the high requirements of sunflower for environmental resources do not exclude early sowing, but rather confirm the relevance of research on their effectiveness.

\section{Received 6 November 2019} Accepted 13 March 2020

\section{REFERENCES}

1. Bailly C. 2000. Antioxidant systems in sunflower (Helianthus annuus L.) seeds as affected by priming. Antioxidant systems in sunflower (Helianthus annuus L.) seeds as affected by priming. Seed Science Research. Vol. 10. P. 35-42. 
2. Buriakov Yu. P. 1992. Yndustryalnaia tekhnolohyia vozdelyvanyia podsolnechnyka. Industrial sunflower cultivation technology. Ahrokhymyia. Vol. 4. P. 27-28.

3. Hospodarenko H. M. 2018. Systema zastosuvannia dobryv. Fertilizer application system. Kyiv: TOV 'SIK HRUP UKRAINA'. 376 p.

4. Kartamyshev N. Y., Tymonov V. Yu., Zelenyn A. V. 2008. Pryemy byolohyzatsyy pry vozdelyvanyy podsolnechnyka. Methods of biologization in the cultivation of sunflower. Zemledelye. Vol. 8. P. 39-40.

5. Kyrychenko V. V., Kolomats'ka V. P., Maklyak K. M., Syvenko V. I. 2010. Vyrobnytstvo sonyashnyku v Ukrayini: stan i perspektyvy. Sunflower production in Ukraine: condition and prospects. Visnyk TsNZ APV Kharkivs'koyi oblasti. Vol. 7. P. 281-287.

6. Kovalenko A. 2016. Optymizatsiia mineralnoho zhyvlennia soniashnyku. Optimization of mineral nutrition of sunflower. Propozytsiia. Vol. 6. P. 62-64.

7. Kovalenko O. O. 2005. Produktyvnist' hibrydiv sonyashnyku zalezhno vid strokiv sivby ta hustoty stoyannya roslyn u pivnichniy pidzoni Stepu Ukrayiny. Productivity of sunflower hybrids depending on sowing time and plant standing density in the Northern Sub-steppe of Ukraine. Avtoref. dys. na zdobuttya nauk. stupenya kand. s.-h. nauk. Dnipropetrovs'k. 19 p.

8. Kramarenko N., Hlushchenko A., Dudiak Y., et al. 1998. Hustota posevov y urozhai. Density of sowing is in a harvest. Zemledelye. Vol. 12. P. 23.

9. Maliyenko A. M. 2015. Deyaki shlyakhy optymizatsiyi rezhymu volohosti gruntu u posivakh polovykh kul'tur. Some ways to optimize soil moisture in field crops. Zemlerobstvo. Vol. 1. P. 68-76.

10. MelnykA.V.,HovorunS.O.2014. Vodospozhyvannia ta urozhainist soniashnyku zalezhno vid sortovykh osoblyvostei ta poperednykiv v umovakh pivnichno-skhidnoho Livoberezhnoho Lisostepu Ukrainy. Water consumption and sunflower yield depending on sort characteristics and predecessors in the conditions of the Northeastern Left Bank Forest Steppe of Ukraine. Visnyk Sumskoho natsionalnoho ahrarnoho universytetu. Vol. 3(27). P. 173-175.

11. Mynkovskyy A. E., Polyakov A. Y. 2007. Produktyvnost' hybryda Zaporozhskyy $28 \mathrm{v}$ zavysymosty ot strokov seva y hustoty stoyanyya rastenyy. The productivity of Zaporizhzhya 28 hybrid, depending on terms of sowing and plant standing density. Naukovo-tekhnichnyi byuleten Instytutu oliinykh kultur NAAN. Vol. 12. P. 225-229.

12. Nosenko Yu. M. 2011. Sonyashnykove riznomanittya. Sunflower variety. Ahrobiznes sohodni. Vol. 1-2. P. 32-33.

13. Nosko B. S. 2013. Azotnyy rezhym gruntiv i yoho transformatsiya $v$ ahroekosystemakh. Soil nitrogen regime and its transformation in agroecosystems. Kharkiv. 130 p.
14. Pokoptseva L. A. 2014. Vplyv peredposivnoi obrobky na produktyvnist soniashnyku u Stepu Ukrainy. The effect of pre-sowing cultivation on sunflower productivity in the Steppe of Ukraine. Tavriiskyi naukovyi visnyk. Vol. 87. P. 75-79.

15. Polyakov O. I., Nikitenko O. V., Vakhnenko S. V. 2014. Formuvannya produktyvnosti hibryda sonyashnyku Kamenyar v zalezhnosti vid ahropryyomiv vyroshchuvannya. Productivity formation of sunflower hybrid Kamenyar depending on methods of growing. Naukovo-tekhnichnyi byuleten Instytutu oliinykh kultur NAAN. Vol. 21. P. 97-104.

16. Pustovoit V. S. 1975. Podsolnechnyk. Sunflower. Moscow: Kolos. 591 p.

17. Sharkovs'ka S. V. 2017. Teoretychni zasady rozvytku rynku sonyashnyku v Ukrayini. Theoretical bases of development of sunflower market in Ukraine. Naukovyy visnyk Natsional'noho universytetu bioresursiv i pryrodokorystuvannya Ukrayiny. Seriya: Ekonomika, ahrarnyy menedzhment, biznes. Vol. 260. P. 367-374.

18. Skydan V. O. 2016. Vplyv temperatur ta volohosti na rozvytok soniashnyku. Influence of temperature and humidity on the development of sunflower. Ahrobiznes sohodni. Vol. 24. P. 48-51.

19. Skydan M. S., Skydan V. O., Kostromitin V. M. 2013. Osoblyvosti nalyvu nasinnya hibrydiv sonyashnyku v umovakh skhidnoyi chastyny Lisostepu Ukrayiny. Features of pouring seeds of sunflower hybrids in the conditions of the eastern part of the ForestSteppe of Ukraine. Tavriys'kyy naukovyy visnyk. Vol. 85. P. 79-83.

20. Tkalich I. D., Mamchuk O. L. 2011. Sposoby sivby ta hustota stoyannya roslyn sonyashnyku hibryda Dariy. Methods of sowing and density of standing plants of sunflower hybrid Dariy. Ahronom. Vol. 1. P. 5.

21. Tkalich I. D., Tkalich Yu. I., Kokhan A. V. 2012. Vplyv sposobiv sivby, pryiomiv dohliadu i dobryv na vrozhainist nasinnia soniashnyku v Stepu. The influence of sowing methods, methods of care and fertilizers on the yield of sunflower seeds in the Steppe. Biuleten Instytutu silskoho hospodarstva stepovoi zony. Vol. 2. P. 128-132.

22. Totskyi V. M. 2014. Vplyv systemy udobrennia ta osnovnoho obrobitku gruntu na formuvannia produktyvnosti soniashnyku. The influence of fertilizer system and basic tillage on formation of sunflower productivity. Naukovo-tekhnichnyi byuleten Instytutu oliinykh kultur NAAN. Vol. 20. P. 204-209.

23. Tsylyuryk A. Y., Sudak V. N. 2017. Vlyyanye osnovnoy obrabotky pochvy y udobrenyy na vodnyy rezhym posevov podsolnechnyka $\mathrm{v}$ severnoy stepy Ukrayny. The influence of basic tillage and fertilizers on the water regime of sunflower crops in the Northern Steppe of Ukraine. Vestnyk Prykaspyya: nauk.-teoret. y prakt. zhurn. Vol. 4(19). P. 13-23. 
24. Tsyliuryk A. Y. 2018. Dynamyka vodnoho rezhyma posevov podsolnechnyka $\mathrm{v}$ zavysymosty ot obrabotky pochvy y udobrenyi v stepy Ukrayny. The dynamics of water regime of sunflower crops depending on tillage and fertilizers in the steppe of Ukraine. Aspekty vozdelyvanyia selskokhoziaistvennykh kultur (za materyalamy XI Mezhdunarodnoi nauchno-praktycheskoi konferentsyy). Horky: BHSKHA. P. 314-325.

25. Tsyliuryk O. I., Desiatnyk L. M. 2017. Vodnyi rezhym gruntu v posivakh soniashnyku. Water regime of soil in sunflower sowing. Ahrobiznes sohodni. Vol. 8. P. 34-40.

\section{Hennady Pinkovsky, Semen Tanchyk \\ SAULĖGRĄŽŲ AUGINIMO TECHNOLOGIJOS UKRAINOS DEŠINIOJO KRANTO STEPĖSE}

Santrauka

Straipsnyje pateikiami technologinių elementų valdymo mokslinių tyrimų rezultatai ir jų ịtaka saulègrąžų produktyvumui Ukrainos dešiniojo kranto stepèse. Tyrimai buvo atlikti NAAS žemès ūkio institute, kuris yra juodosios žemès zonoje (Ukrainos dešiniojo kranto stepè).

Saulègrąžų produktyvumą lemia vandens ir dirvožemio santykis. Vandens režimą formuoja oro sąlygos, dirvožemio drègmès atsargų ir kritulių kiekis, jų intensyvumas. Augalų drègnio atsargos metro dirvožemio sluoksnyje prieš sėją, žydejjimo fazejje ir prieš derliaus nuėmimą tyrimų metais buvo skirtingos ir priklausè nuo auginamų augalų tankio. Saulègrąžoms ypač svarbus drègmès kiekis $0-100 \mathrm{~cm}$ dirvožemio sluoksnyje, kai suformuoja krepšelius. Šiuo laikotarpiu saulègrąžos intensyviai naudoja turimą drègmę iš gilesnių dirvožemio sluoksnių.

Azoto, fosforo ir kalio kiekis bėgant metams smarkiai skyrèsi ir buvo jaučiama skirtingų trąšų fono įtaka. Azoto trąšų derinimas su fosforu ir kaliu $\mathrm{N}_{40} \mathrm{P}_{40} \mathrm{~K}_{40}+\mathrm{PP}$ ir $\mathrm{N}_{40} \mathrm{P}_{40} \mathrm{~K}_{40}$ gerina dirvožemí, sukuria palankesnes sąlygas saulėgrąžoms augti ir vystytis. Tokiomis sąlygomis didžiausias derlius buvo gautas iš LG 55.82 hibrido, augalų tankis siekè 60 tūkst. ha, per pirmąji sëjos laikotarpi - 3,85 t/ha.

Atsižvelgiant i ekonominius rodiklius yra efektyvu auginti LG 54.85 ir LG 55.82 hibridus pirmąji sėjos laikotarpi. LG 56.32 saulègrąžų hibrido didžiausias ekonominis efektyvumas pasiekiamas trečiąji sẻjos periodą. Tarp hibridų ekonomiškai tinkamiausia auginti LG 55.82, kai sejjama esant $5-6{ }^{\circ} \mathrm{C}$ dirvos temperatūrai ir 60 tūkst./ha augalų. Šio varianto grynasis pelnas buvo $22043 \mathrm{UAH} /$ ha, pelningumo lygis siekè 224,1 \%.

Didžiausias energijos efektyvumo santykis buvo pirmąji LG 55.82 hibrido sejos periodą ir sudare 4,44 t/ha.

Raktažodžiai: saulègrąžos, hibridai, sėjos laikas, auginamų augalų tankis, dirvožemio maistinių medžiagų režimas, dirvožemio vandens režimas, derlius 